\title{
Progress and achievements in geological work in China
}

\section{The management of geological work}

\section{The administrative structure}

Through 40-odd years of endeavour, China has buith up a qualified geological exploration contingent which can undertake all types of professional work using relatively advanced technical aquipment. There are 100000 geological professionals working in various organisations affiliated respectively to 11 departments or industrial sectors (geology and mineral resources; metallurgy; non-ferrous metals: coal; petroleum; offshore petroleum; nuclear materials; building materials; chemicals, light industry, and the Gold Headquarters). The Ministry of Geology and Mineral Resources (MGMR) is responsible for the administration of the geological exploration sector. Funds for advanced geological exploration work of public benefit and strategic significance are allocated by the central government in a unified way, while for greological exploration projects of benefit to departments, institutions and enterprises, a market mechanism is gradually being introduced with the ain of merging exploration and development into an organic whole. The necessary funds will be invested by the users according to the principle of "those who benefit shall bear the input'.

In addition to the MGMR there are administrative departments and/or sections of geology and mineral resources at provincial, prefectural (municipal) and county levels. The principal function of the MGMR is to administer, on behalf of the State Council, the mineral resources, geological environments and geological exploration over the whole country. Its main tasks are to provide mineral resources and geological data: maintain the State ownership of mineral resources; protect geological environments; manage the geological exploration sector, and to investigate new administrative structures for China's geological survey and mineral exploration undertakings. The departments of geology and mineral resources at provincial, prefectural (municipal) and county levels administer geological exploration, manage mineral resources and supervise their development and utitisation. To meet its obligations, the MGMR has set up 11 functional departments (bureaus) and other supporting and serviceoriented geological exploration organisations including five national research institutions (the Academy of Geological Sciences, the Geology and Mineral Resources Information Institute. the Geological Economics Institute, the Hydrogeological and Engineering Geological Exploration Institute and the Geological Exploration Techniques Institute). In addition, there are technical, policy and legal advisory agencies such as the MGMR Senior Advisory Centre and the MGMR Policies and Legal Regulations Research Centre as well as various societies and associations. Necessary management bodies have been established within local geological exploration depart ments according to the needs of geological exploration assignments

\section{The legal framework}

Following political reform and the adoption of a policy of openning to the outside world in China, the legal system covering geology and mineral resources has been progressively strengthened and is being steadily perfected. In 1986, the National People's Congress promulgated the 'Mineral Resources Law' following which the State Coun- cil sucessively issued or approved. an number of statutory rules and regulations pertaining 10 :

- the rational development, protection and supervision of geological and mineral resources:

- the comprenensive management of geological and mineral resources:

- the sectoral managenent of geological exploration work, and

- the supervision, evaluation and management of geological environments.

In 1994, a number of important administrative rules and regulations were patsed including the Implementational regulations of the Mineral Resources Law" and "Management Rules on Mineral Resources Compensation". A series of other important rules and regufations, including the annendment to the Mineral Resources Latw. 'Administration Regulations on Foreign Fims-Funded Explontion and Mining Mineral Resources and 'Management Regulations on Environmental Protection of Mines are beine drafled.

\section{Achievements in geological work}

\section{Basic geological survey}

Extensive basic surveys have been carried out. We have completed the regional geological survey on the scake of $1: 1000000$ over the total area of $9600000 \mathrm{~km}^{2}$. the 1:200000)-scale regional geological survey over $70 \%$ of the total area, and the $1: 200000$ to $1: 500000$ scale regional hydrogeological reconnaissance over $8200000 \mathrm{~km}^{2}$. Regional geophysical geochemical surveys and marine geological surveys have also made significant advances.

We have compiled and published maps and atlases at various scales, and monographs on geokgy. mineral resources, tectonics. palaeogeography, hydrogeology. engineering geology and so on. From these works, we nor only have acquired a considerable understanding of the overall picture of the geology and structure of the country, but also achieved a series of impontant results in basic geology and abundant information on mineral prospecting.

\section{Evaluation of mineral resources}

Large amounts of minesal resources have been proved. basically guaranteeing the needs of cconomic construction. One hundied and sixty eight varieties of mineral resources have been found, of which 151 have proved reserves. China is one of the few countries that have an almost complete range of mineral commodities and abundant proved reserves and leads the world in terms of the proved reserves of 25 minerals (coal. vanadium, titanium. lead. zinc. molybdenum, tungsten, tin. lithium. nickel, rare earths. mercury, antimony, niobium, masnesite, graphite,asbestos, fluorite and barite). For most minerals, the proved reserves can cope with or satisfy the near-term demands of the national economic construction and some minerals are even sufficient for long-term exportation. The abundant mineral exploration findings have promoted the development of the mining industry, thereby bringing about the establishment of over 9000 state-owned mines and more than 260000 collectively run mines and individually operated mining sites and the emergence of 200 odd mining cities and towns all over the country. 


\section{Hydrogeology, engineering geology and the environment}

Substantial hydrogeological, engineering geological and environmental geological investigations have been conducted to meet the basic needs of economic construction, social development and people's livelihood. In groundwater resource exploration, thousands of water-source sites have been assessed for a large number of cities, industrial and mining enterprises, and agricultural and pastoral areas. Regional water resources assessments have been made in the light of the transformation relationship of the 'three waters' (atmospheric water, surface water and groundwater), providing a scientific basis for the rational utilisation of water resources. Substantial engineering geological investigations and evaluations have been made for the harnessing of major rivers, and the construction of railways and bridges, major capital construction projects and underground engineering projects. A great number of investigations and studies of environmental geological problems have also been carried out to control geological hazards, such as land subsidence, earthquakes, landslides, debris flows etc.

\section{Geological methods and technology}

Major advances have been achieved in geological science and technology, as reflected in the following:

\section{Studies of mineral deposits}

Through the discovery of several large petroleum provinces such as the Songliao and north China petroleum provinces, geological theory on the formation of large oil fields in basins or depressions essentially of continental facies deposits has been enriched. The metallogenic sequence concept of mineral deposits and new ideas such as the "tri-source metallogenesis" (a prognostic method based on orewater-and heat-sources) have upgraded the research level in mineral deposit studies and resulted in the discovery of a series of new and important mineral deposits in China.

\section{Stratigraphical and palaeontological studies}

A nationwide unified chronostratigraphic classification and correla tion system has been basically established, and a number of internationally acknowledged standard stratotype sections have been erected. Over 400 new genera and more than 6000 new species have been found, and significant findings have been recorded in palaeoanthropological studies.

\section{Petrological and mineralogical studies}

Petrological studies in China have entered a new stage in which descriptive petrology is combined with data on geological settings and structural features. Mineralogical studies, in which highly advanced technologies are used, have resulted in the discovery of over 100 species of new minerals. Meanwhile a wealth of mineralogical data have been provided for geological surveys, mineral prospecting and ore beneficiation.

\section{Studies of structural geology}

A number of tectonic theories, initiated by noted geologists like Professors Li Siguang (J S Lee), Huang Jiqing (T K Huang) and Chen Guoda have made positive contributions to studies of China's metallogenic features and prognosis of ore deposits. So far, a total of 11 deep geoscience transects have been mapped, as a result of which the basic structure of the continental crust of China has been preliminarily outlined.

\section{Other studies}

Major developments have also been made in studies relating to multi-purpose utilisation of mineral resources, geophysical and geochemical prospecting, remote sensing, drilling, laboratory testing, computer data processing and mapping and cartography.

\section{Research and education}

China has altogether 98 geoscientific research institutions with a total of 21000 technical professionals, carrying out geological scientific and technological research and development work in different fields. Nearly 1000 scientific research projects are completed annually. There are eight geological colleges or universities, 53 other institutions of higher learning offering geoscience specialities, and geological secondary schools and geological higher learning institutions for adults. Together they have served to train thousand of geological professionals, who have become the backbone of geoscientific research.

\section{International cooperation}

So far, China has joined 31 international geoscience-related organisations and maintains contacts and associations with eight United Nations organisations (UNDP, UNESCO, etc.). China was an active participant at the 25th-29th Sessions of the International Geological Congress (IGC). Prof Zhang Binxi and Prof Liu Dunyi from China were elected Vice-President of IUGS at the 27th and 29th Sessions. respectively. At the 28 th and 29 th Sessions of $\mathrm{IGC}$, it was decided that the 30th IGC will be held in China in 1996 and active preparations are now underway.

The multi-lateral scientific and technological exchanges are unprecedentedly active and are developing in diversified forms. China has developed nearly 100 joint research projects with foreign organisations and there have been about 1000 instances of academic exchange, covering almost all fields of geoscience. China's geological companies, involving external business, have been participating in the competition for contracted engineering projects on the international market, and are developing economic cooperation with other countries.

\section{The prospects for geological work}

The 15 years from 1996 to 2010 will be a critical period for development of national economic construction of China, and the geological work should be done in advance.

In basic geological work, the 1:200 000-scale nationwide firstgeneration regional geological survey covering the entire land area of the country will be completed and a new round of 1:250000-scale regional surveys will be launched in the period of the Ninth FiveYear Plan (1996-2000). The pace of the 1:50 000-scale regional geological survey will be accelerated, and researches on regionalisation and metallogenic prognosis will be continued.

In mineral exploration work, oil and gas exploration will be highlighted. In coal exploration, stress will be laid on expanding the explored reserves in coal deposits, increasing the surveyed reserves and reinforcing research work on the exploration and development of coal-bed gas. Exploration for precious metals ( $\mathrm{Au}, \mathrm{Ag}$, etc.) and copper resources will be strengthened. Prospecting for other nonferrous metals and mineral resources used for chemical fertilizers will be carried out in in response to demand in specific areas and according to local conditions.

Hydrogeological and engineering geological and environmental geological surveys will be carried out in the light of economic construction. The improvement of people's livelihood will similarly be taken into account. Work on the prevention and control of geological hazards will also receive attention.

In geological scientific and technological research work, keytask research, oriented research, and the popular dissemination of research results will be organised centering on the major scientific and technological problems in fundamental geology, mineral exploration, rational utilisation of mineral resources, and geological environment protection, so that the knotty problems in geological survey and mineral prospecting may be promptly solved. 
With respect to the management of geological work, it is necessary to explore and establish a socialist management system which bears Chinese characteristics. Meanwhile, the administration of the whole geological exploration sector must be strengthened to ensure the normal operation of geological exploration work. In the case of mineral resources management, it is necessary to strengthen the planning, distribution and management of mineral resources; to maintain the State ownership of mineral resources; to intensify the supervision and administration of mineral resources development, and to establish a compensation mechanism for the possession and consumption of mineral resources and a system for the compensated use of mineral resources. Finally, there is a need for a monitoring and information network to publicise reports, and warnings in cases of emergency, on the quality of geological environments, and to strengthen the supervision and administration of them.
Xun Zhu is a Senior Geologist. He was the Minister of Geology and Mineral Resources from 1985 to 1994, and is also President of the Geological Society of China. He is presently the Secretary-General of the National Committee of the Chinese People's Political Consultative Conference. He was in charge of the exploration of a number of major copper deposits such as the Dexing copper mine in Jiangxi, as well as surveys of some large- and mediumscale $\mathrm{Pb}-\mathrm{Zn}, \mathrm{Mn}, \mathrm{Nb}-\mathrm{Ta}$ and serpentine deposits.

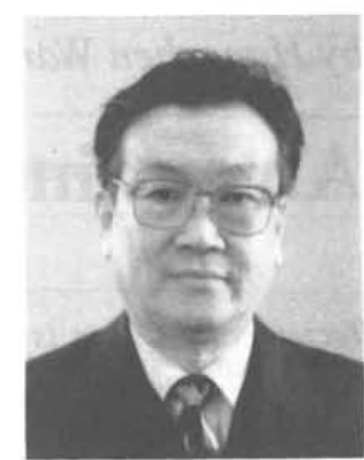

